\title{
The Policy of Surabaya Municipality In Developing Sustainable Urban Infrastructures By Conserving Urban Heritage
}

\author{
Lilik Pudjiastuti \\ Law Faculty, Airlangga University \\ Surabaya, Indonesia \\ pudjiastutililik@yahoo.com
}

\begin{abstract}
Cultural heritage conservation is related to tangible heritage and is often classified as immovable heritage and movable heritage. A city heritage; a part of it includes historical sites which is considered as a cultural heritage that possesses typical styles and architectural characteristics wherein past values are embedded. Thus, urban heritage as urban treasure can actually serve as the main resource in creating a city image/branding. Rapid growth of modernization and globalization seems to have pushed aside the urban heritage which is located in the city. Surabaya is the City of Heroes which has a lot of monument and historical buildings as cultural heritage conservation. Therefore, the local government of Surabaya is required to implement an inclusive, safe, strong and sustainable policy of urban development by maintaining urban heritage and exploiting it without removing its characteristics and underlying value as existing self-identity and pillars as the City of Heroes in order to realize Goal 11 of Sustainable Development Goals (SDGs) 2030 or Sustainable Development Goals (SDGs) as the target.
\end{abstract}

Keywords-Government policy; authority; property rights; cultural heritage buildings; and urban heritage control.

\section{INTRODUCTION}

Surabaya is commonly addressed as the city of heroes wherein its city architectural values possess potential cultural heritage for cultural heritage conservation. The city architectural works conservation related to colonial buildings as well as historical track record depicted in old, unique, and rare buildings has been a real challenge in the globalization era with priority on the dominant economic sector.

Surabaya, in its advancement, has turned into a city of service, trade, transit center in the East
Indonesia territory in which the Ministry of Culture and Tourism has listed Surabaya as one of the top ten MICE cities in Indonesia. The rapid development of Surabaya has resulted in some problems regarding with expansions, land use, urban society handover which leads to conflicts on sites of cultural heritage conservation.

In Surabaya, efforts for conserving and documenting the city architectural heritage were commenced simultaneously as the enactment 188.45/251/402.1.04/1996 of the Surabaya Mayor was issued on 26 September, 1996 which regulated 61 cultural heritage sites as the protected object of cultural heritage conservation. The enactment of No 5, 2005 of Local Government of Surabaya on Cultural Heritage Sites as the follow up of Acts No 5, 1992 on Cultural Heritage. As a matter of fact, such efforts to preserve cultural heritage sites in Surabaya is beyond reach ; many cultural heritage sites remain abandoned and disfigured in terms of its shape or structure, and/or excavated or removed as what had happened to the building of radio station once belonged to Bung Tomo, the alteration of Semut Railway Station, or the hospital of Mardi Santoso.

By enacting Actss No 11, 2010 on Cultural Conservation, the Government has stipulated legal relations between cultural heritage owners and the government on cultural heritage stipulation, and efforts of management, conservation and manipulation of cultural heritage to function as the urban treasure trove which is a significant part in creating a city image/ branding. The fast growing modernization and globalization appears to have shifted existing urban heritage in a city. Consequently, it requires a comprehensive study from legal, social and economic aspects to settle cultural heritage issues in Surabaya. 


\section{PURPOSE}

The aim of this paper is to learn about the government's policy in fulfilling its duties and responsibilities to provide protection for the preservation of cultural heritage as a culture and characteristic of the city, while still providing protection to one's property rights over buildings designated as cultural heritage. Thus preservation of cultural heritage by the government of Surabaya to create city branding does not harm a person's right of ownership.

The government, provincial government, local government, and society are obliged and responsible for conservation of cultural heritage sites. Yet, there are some problems arising in the conservation of cultural heritage sites in Surabaya which include:

1. The policy of Surabaya Municipality in stipulating cultural heritage sites by maintaining the proprietary rights of its owner as part of human rights.

2. Efforts of the Surabaya Municipality in prescribing policy of cultural heritage by maintaining the dynamic city accomodation.

\section{METHODS}

The research method is carried out through the investigation of legislation in accordance with the problems followed by the interpretation and analysis of the legislation to answer the legal issues. The legislation studied includes the 1945 Constitution of the State of the Republic of Indonesia, Acts Number 11 Year 2010 involving Culture, Regional Regulation of Surabaya Number 5 Year 2005 concerning preservation of Cultural Heritage Building and Environment, the Mayor's Regulation and Decree of the Surabaya Mayor as the implementation of the laws and regulations.

\section{RESULTS AND DISCUSSION \\ I. Authority of Surabaya City in Establishing Cultural Heritage}

As the city of Heroes, Surabaya has urban heritage defined as monument, site and infrastructure, hence, the Surabaya Municipality is obliged to conserve the existing heritage. The authority of Surabaya in prescribing the cultural heritage conservation is stipulated in Section 12 Acts No 23, 2014 on the Local Government and Section 95 and 96 Acts No 11, 2010 on Cultural Heritage. The efforts in cultural heritage conservation in Surabaya are carried out through some legal instruments defined as:

a. No 5, 2005 of the Surabaya Municipality Regulation in Conservation of Sites, and/or Cultural Heritage areas;

b. No 59, 2007 of The Mayor of Surabaya Regulation in the enactment of No 5, 2005 of the Surabaya Municipality Regulation in Conservation of Sites, and/or Cultural Heritage areas as it has been amended with The Mayor of Surabaya Regulation of No 48, 2008 of the First Amendment on No 59, 2007 of the Surabaya Mayor Regulation in the enactment of No 5, 2005 of the Surabaya Municipality Regulation on Conservation of Sites, and/or Cultural Heritage areas as it has been amended twice with The Mayor of Surabaya Regulation of No 19, 2011 on the second amendment of No 59, 2007 in the enactment of No 5, 2005 of the Surabaya municipality regulation on conservation of sites, and/or cultural heritage areas.

c. No.17, 2014 of The Mayor of Surabaya Regulation on Methods of Reducing, Dispensing, Discarding fees for Using Cultural Heritage Sites.

d. The Stipulation of the Surabaya Mayor which declares cultural heritage sites, thereof 22 stipulations of the Surabaya Mayor have been made since 1996-2012 which declare 160 cultural heritage sites and areas existing in Surabaya.

By referring to the above legislation, the Surabaya Mayor is authorized to declare cultural heritage sites and areas with the criteria of: having at least 50 (fifty) years of age, having aesthetic, architectural design and style dated back to a particular era; plurality; rarity, historical value to Surabaya which strengthens the respective areas with the sites and/ or parts of the city; its existence can affect the surrounding as well as enhance quality and image of the surrounding environment, 
authenticity of cultural heritage sites, specialty of landmark in forms of the Mayor Stipulation.

In practice, the sites designated as cultural heritage in Surabaya are any sites which belong to the government, local government, or private property. Hence, the sites declaration as cultural heritage can diminish the rights of its owner. The reduced proprietary rights of the cultural heritage sites is regulated in legislation and the municipality regulation of Cultural Heritage; the owner and/or guardian of cultural heritage is obliged to seek the Mayor's agreement if at times the cultural heritage site is to be reconstructed, renovated, used, and/ or taken over.

On one side, cultural heritage conservation aims to cater to public needs for art, culture, and tourism enhancement as it is stipulated on Section 32, sub section (3) of the Constitution of RI, 1945. On the other hand, conservation and manipulation of cultural heritage can potentially result in diminishing the owner's rights. The proprietary rights respective to human rights are stipulated in Section 17 of the Universal Declaration of Human Rights) which states that everybody is entitled to own their property and its relations to other rights, and strictly forbids seizure over the property by force. 1 Consequently, in terms of national mandatory in respecting ownership rights: the state has to restrain from interfering with someone's property rights.

The 1945 Constitution of RI has recognized someone's property rights as stipulated in Section $28 \mathrm{G}$ sub section (1): everyone is entitled to have protection of oneself, family, honor, dignity, and property under their jurisdiction as well as safety, protection from threats and fear from taking any actions defined as their rights. Yet, Section $28 \mathrm{~J}$ sub section (2) of the 1945 Constitution of RI has explicitly given the provision on limitation of proprietary rights; in implementing their rights and freedom, everyone has to comply with the limitation regulated by legislation in order to secure recognition and honor of freedom and rights of others as well as to cater to justice in accordance with moral considerations, religious values, safety, and general order in a democratic society. Accordingly, Section 28 sub section (2) The 1945
Constitution of RI, the legislation of Cultural Heritage has recognized the property rights in:

a. Section 12 sub-section (1): that everyone is capable of possessing, and/or taking over objects, structures, and/or sites of cultural heritage by paying attention to their social functions provided that it is in accordance with the regulation stated in the legislation.

b. Section 16: that cultural heritage owned by everyone can be expropriated by the government or every other person wherein the expropriation can be conducted through a grant, trade, gift, acquisition, compensation, and/or stipulation or court verdict.

c. Section 22: that everyone who owns or takes over cultural heritage is entitled to compensations once they have completed their obligation to protect the cultural heritage.

d. Section 24: that everyone is entitled to receive compensations once they find objects, sites, structures, or locations designated as cultural heritage.

e. Section 33: that each owner of cultural heritage is entitled to possess legal protections in forms of the reference of cultural heritage status; and b. the proprietary reference based on the lawful evident after the cultural heritage is listed on the national register.

f. Section 78: that everyone can extend the cultural heritage after having acquired a. the government or local government license; and $b$. the owner's and/ or the custodian's permission.

\section{Urban heritage in Shaping City Branding}

The heritage of a city, one of it comprises of historical remnants which are the cultural heritage wherein styles and typical architecture contains values of the past. One example of urban heritage commonly seen in a city is monuments and areas of the old city which were intentionally developed with a particular value and purpose. According to the data provided by the Department of Tourism and Culture of Surabaya Municipality, the cultural heritage existing in Surabaya is listed as follows: 


\begin{tabular}{|l|l|c|}
\hline No & \multicolumn{1}{|c|}{ Category } & Unit \\
\hline 1. & Building/office \\
& $\begin{array}{l}\text { a. Government/state-owned } \\
\text { enterprise; } \\
\end{array}$ & 15 \\
\hline 2. & Monuments & \\
\hline 3. & Public Building & 12 \\
& a. Hotel & 10 \\
& b. Bridge & \\
& c. Hospital & 4 \\
& d. Orphanage & 4 \\
& e. Sport Center & 8 \\
& f. Correctional Institution & 3 \\
& g. Auditorium & 6 \\
& h. Station & 2 \\
\hline 4. & Religious Service & 4 \\
\hline 5. & School/ Educational Building & 10 \\
\hline 6. & Real Estate/ Private Residence & 16 \\
\hline 7. & Shop or Shopping Complex & 10 \\
\hline 8. & Neighbourhood/ district & 8 \\
\hline 9. & Cemetry & 5 \\
\hline & & \\
\hline
\end{tabular}

According to Santoso, the idea of a monument is not only limited to events, but also is an idea to show reflection, essence, and meaning underlying it. 2 The existence of an old city, as a matter of facts, is the beginning of a city growth as well as the center of advancement and the city history. Therefore, Handoko stated that urban heritage conservation is a strategic approach in the city development since the effort to conserve urban heritage can secure sustainable values of life in the development process in it. 3

Referring to the decree of the Indonesian Heritage Conservation declared in Ciloto 13 December, 2003 that heritage was declined to be the Indonesian heritage. 4 Astuti explained that urban heritage as the city heritage can actually be an important part of creating city branding. Furthermore, she said that one of the strongest aspects to create city branding is the city image as a typical image attached to the city which can represent the city to public or visitors. 5

The fast growing modernization and globalization appears to have shifted urban heritage existing in a city. The policy of Surabaya Municipality in conducting cultural heritage preservation to maintain the branding of Surabaya involves:

a. Classifying cultural heritage sites into 4 groups:

1. Category A is any cultural heritage site that must sustain through preservation efforts;

2. Category B is any cultural heritage can be restored through restoration/rehabilitation and reconstruction;

3. Category $\mathrm{C}$ is any cultural heritage can be restored through revitalization/ adaptation.

4. Category D is any cultural heritage site on any areas considered as dangerous to its user or surrounding environment, therefore it can be demolished and reconstructed similarly to its original shape.

b. The cultural heritage team, therefore can recommend people in charge of restoration and/or exploitation of the cultural heritage site based on the defined classification.

c. The recommendation of the cultural heritage team is employed by Dinas Cipta Karya to issue the license of erecting infrastructure as a requirement in cultural heritage restoration by adjusting it with the city layout of Surabaya.

d. The provision enacted by the Surabaya Municipality in restoring and/ or exploiting cultural heritage site for any activities or business that has to be administered with recommendations is an effort to prevent cultural heritage sites from modification as well as functional transformation to maintain historical legacy as it gradually fades away. Many historical buildings in which lie their priceless value have been destroyed and demolished for opening the landsite for new infrastructures with higher commercial values, 6 The advancement in urban areas, inevitably, has turned the society into more individualistic being and consequently, have less concerns toward their environment and the existing urban heritage. 7

With the enactment of Laws No 11, 2010 of Cultural Heritage, the classifications of cultural heritage based on national, provincial and regional/ municipal ranking with specific terms and conditions have been authorized to each 
government administrator. With the directives available for ranking cultural heritage as the responsibility of each government administrator in implementing conservation, the administrator is permitted to provide classification of cultural heritage sites as a guideline to implement restoration and/or manipulation as stipulated by the Surabaya Municipality. The classification provision is required for cultural heritage preservation since it corresponds to the cultural heritage laws which define cultural heritage preservation as a dynamic effort to sustain the existence of cultural heritage and its value by protecting, developing and manipulating it.

Regarding with the stated concept of cultural heritage, the Surabaya Municipality maintains the functions of historical sites and areas of Surabaya as the branding of heroes city whilst developing the city. Such efforts must be supported by legislation and public provision of good governance. The efforts of the Surabaya Municipality in creating the branding of heroes city by exercising urban heritage is carried out through

a. Identifications on some sites and areas of Surabaya heritage as the city of heroes supplied with complete documentations, either pictures and their descriptions which later are designated as cultural heritage by the Mayor of Surabaya;

b. Considerations on heritage locations in the regional layout and detailed master plan of city layout in forms of local regulations wherein the regulation has been the foundation and guideline in issuing the license of erecting infrastructure and its exploration;

c. Formation of cultural heritage team as a group of conservation experts from different backgrounds of study whose competency

certification enable them to give recommendation to the Mayor for designating, ranking, restoring, exploring, and removing cultural heritage as stipulated in the Mayor Decree;

d. Issuing the license of erecting infrastructure and its exploitition for the sites used as urban heritage;

e. Providing financial incentives and/ or facilities to people or bodies who take care of and/ or explore cultural heritage as stipulated in bylaws (local regulations or the Mayor regulation)

f. Listing the location of cultural heritage in the tourism of Surabaya; and

g. Supervising and mentoring the cultural heritage stewards.

The Surabaya Municipality can conduct cultural heritage conservation accordingly based on No 5 the Regulation of Surabaya Municipality No 5, 2005 of Conservation of Cultural Heritage Sites and Areas. Thereof the passing of Acts No 11, 2010 of Cultural Heritage results in a discrepancy in the Regulations of Surabaya Municipality of conservation cultural heritage sites, for instance:

a. The regulation of Surabaya Municipality of No 5, 2005 does not accomodate the city dynamics. Therefore, in practice, the conservation of cultural heritage do not necessarily meet the urban heritage concepts.

b. The regulation of Surabaya Municipality of No 5, 2005 which regulates the formation of Cultural Heritage Team does not meet the stipulation of team formation and requirements for the Cultural Heriage Team as regulated in Laws No 11, 2010 of Cultural Heritage.

\section{CONCLUSION}

a. Cultural heritage conservation is a dynamic effort to preserve the existence of cultural heritage and its values by protecting, developing, and exploiting it. Thus, the effort may diminish proprietary rights of the owner of cultural heritage. Therefore, compensations must be given to the owner for the reduced rights, in order to respect their proprietary rights as part of human rights. The compensations may be given either in forms of financial incentives or others.

b. Sites and/or areas of cultural heritage is a heritage of a city history. Moreover, urban heritage has to be taken into consideration, particularly in creating city branding whilst developing the local area. With the existence of urban heritage, the conservation of cultural heritage shall no longer be worth safeguarding since it has served as a capital venture in its development without removing its characteristics. 


\section{SUGGESTIONS}

By passing the Acts No 11, 2010 of Cultural Heritage, the regulation of Surabaya Municipality of No 5, 2005 of Cultural Heritage has to be evaluated accordingly to correspond to the existing by-laws regulation. Yet, the stipulation of cultural heritage as Category A, B, C, and D has to remain the instrument for restoration and/or manipulation of cultural heritage within urban heritage in spite of its absence in the actss of cultural heritage.

\section{REFERENCES}

[1] Catarina Krause, Hak Atas Kepemilikan, dalam bukuHak Ekonomi, Sosial dan Budaya, h. 208.

[2] Santoso, S. P. TA: Perancangan Buku Monumen Bersejarah Sebagai Upaya Pelestarian Cagar Budaya di Kota Surabaya. STIKOM Surabaya, 2012.

[3] Handoko, I. Ta: Evaluasi Klasifikasi Bangunan Bersejarah Di Kota Tua Jakarta Berdasarkan Kebijakan Kawasan Cagar Budaya Melalui Penentuan Prioritas Konservasi. Universitas Diponegoro, 2006.

[4] Bramasta, D., Rindarjono, M. G., \& Sarwono, S. Proses Keruangan Pelestarian Saujana Budaya Kota (Urban Heritage) Di Kecamatan Laweyan Kota Surakarta Tahun 2013 (Kajian Pelestarian Cagar Budaya Di Kecamatan Laweyan Kota Surakarta). Geoeco, 2015.

[5] Astuti, N. R. Identifikasi Peran Pusaka Perkotaan Dalam Pembentukan Citra Kota Surakarta. Jurnal Internal Program Studi Sarjana Perencanaan Wilayah Dan Kota Sappk ITB.

[6] Santoso, S. P. TA: Perancangan Buku Monumen Bersejarah Sebagai Upaya Pelestarian Cagar Budaya di Kota Surabaya. STIKOM Surabaya, 2012. 
